\title{
Kebahagiaan Ditinjau dari Status Pernikahan dan Kebermaknaan Hidup
}

\author{
Mauliawati Fatimah, Fathul Lubabin Nuqul \\ Fakultas Psikologi Universitas Islam Maulana Malik Ibrahim Malang \\ email: liamauliawati2@gamil.com, lubabin_nuqul@uin-malang.ac.id
}

\begin{abstract}
Abstrak
Kebahagiaan merupakan emosi positif yang diharapkan semua orang. Banyak riset terdahulu yang di dukung dengan anggapan umum bahwa kebahagiaan bisa diperoleh dari pernikahan. Selain pernikahan, kebahagiaan seseorang akan didapat dari hidup yang lebih bermakna. Fenomena yang kontradiktif didapat dari data survei BPS 2017 menunjukkan bahwa indeks kebahagiaan orang yang belum menikah lebih tinggi dibanding yang menikah. Penelitian ini bertujuan untuk membuktikan bahwa pernikahan dan kebermaknaan hidup mempengaruhi kebahagiaan. Subyek dalam penelitian ini adalah mahasiswa sejumlah 79 orang belum menikah dan 60 orang telah menikah.Pengukuran dalam penelitian ini menggunakan skala Oxford Happiness Inventory $(\mathrm{OHI})$ untuk mengukur kebahagiaan, dan skala The Brief Personal Meaningful Profile (PMP-B) untuk mengukur kebermaknaan hidup. Hasil menunjukkan bahwa kebahagiaan tidak dipengaruhi status, namun lebih dominan dipengaruhi oleh kebermaknaan hidup.
\end{abstract}

Kata kunci: Kebahagiaan, Kebermaknaan Hidup, Status Pernikahan.

\section{Happiness Viewed from the Status of Marriage and Meaningfulness of Life}

\begin{abstract}
Happiness is a positive emotion that is expected by everyone. Many previous studies support the general assumption that happiness can be obtained from marriage. In addition, a person's happiness will be obtained from a more meaningful life. A contradictory phenomenon is obtained from BPS 2017 survey data, indicating that the happiness index of people who are not married is higher than those who are married. This study aims to prove that marriage affects happiness. The subjects in this study were 79 students who single (never married) and 60 married. Measurements in this study used the Oxford Happiness Inventory $(\mathrm{OHI})$ scale to measure the happiness and scale of The Brief Personal Meaningful Profile (PMP-B) to measure meaningfulness of life. The results show that happiness is not influenced by marital status, but more dominantly influenced by meaningfulness of life.
\end{abstract}

Key word: Happiness, Meaning Life, Marital Status

\section{Pendahuluan}

Kebahagiaan merupakan wujud

kesempurnaan, sehingga banyak orang yang

berusaha mewujudkannya. Kebahagiaan merupakan emosi positif yang paling bermakna (Rahardjo, 2007). Bahkan sepanjang hidup, manusia berfokus untuk mencapai kebahagiaan dengan berbagai cara. Secara psikologis terdapat 14 faktor yang mempengaruhi kebahagiaan seseorang antara lain penghasilan yang diperoleh, usia, agama, budaya, bersyukur kepada Tuhan, aktifitas fisik, kualitas hidup, memaafkan, hubungan sosial dengan orang lain, menikah, 
kesehatan, silaturahmi, hubungan baik dengan keluarga.Lebih lanjut Waldinger (dalam Mineo, 2017) mengungkapkan bahwa perkembangan kebahagiaan terbaik berada pada mereka yang memiliki hubungan baik dengan keluarga, teman, dan komunitas.

Pernikahan merupakan salah satu pediktor lingkungan yang memiliki pengaruh kuat terhadap kebahagiaan (Bailey \& Fernando, 2012).Robert Waldinger (dalam Mineo, 2017)tiga poin utama yang menentukan kebahagiaan, yakni jalinan hubungan yang dekat, kualitas suatu hubungan, serta pernikahan yang stabil dan saling memdukung. Waldinger mengungkapkan bahwa selama 75 tahun penelitiannya menunjukkan bahwa perkembangan kebahagiaan terbaik berada pada mereka yang memiliki hubungan baik dengan keluarga, teman, dan komunitas.

Secara psikologis orang yang menikah cenderung hidup lebih lama dan lebih sehat dibanding yang belum atau tidak menikah (Doblhammer dkk., 2009)individu yang menikah memiliki tingkat kesejahteraan yang lebih tinggi (Dush \& Amato, 2005: Soulsby \& Bennett, 2015)hal ini karena individu yang menikah cenderung mendapat dukungan sosial yang lebih. Deiner, dkk(1999) mengungkapkan bahwa seseorang dengan skor kesejahteraan subyektif tinggi akan memiliki emosi positif dan sedikit emosi negatif, terlibat dalam berbagai aktifitas menyenangkan dan memiliki kepuasan hidup, lebih disukai,hidup lebih lama hidup memiliki penghasilan yang lebih baik, serta lebih sedikit terlibat perceraian.

Penelitian secara longitudinal tentang pengaruh positif pernikahan yang dilakukan oleh Wilson dan Andrew (2005)menunjukkan bahwa individu yang menikah jauh dari penyakit psikologis. Hal ini di dukung Gove, Style, \& Hughes. (2015)yang mengemukakan bahwa pernikahan membuat seseorang hidup lebih lama, membuat lebih sehat dan lebih bahagia, baik laki-laki maupun perempuan mendapatkan kebaikan atau manfaat dari pernikahan, meskipun para peneliti menemukan bahwa laki-laki mendapat keuntungan yang lebih. Keuntungan itu bukan hanya karena orang yang menikah lebih sedikit terpapar perilaku yang beresiko, namun kualitas pernikahan serta kepercayaan mempengaruhi besar kecilnya keuntungan yang diterima (Wilson \& Oswald, 2005).

Kenyataan di Indonesia sendiri, tingkat kebahagiaan dalam pernikahan mengalami penurunan.Berdasarkan data statistik yang ada, penurunan tingkat pernikahan terjadi selama tahun 2014-2015 dariindeks 59,88 menjadi 59,65 . Secara umum tingkat kebahagiaan pada tahun 2017 adalah 70,69. Namun jika dilihat dari status pernikahan, orang yang belum menikah lebih bahagia dibanding mereka yang telah menikah.Indeks kebahagiaan orang yang telah menikah sebesar 71,09dan 71,53 pada mereka yang belum menikah. Adapun dimensi dalam mengukur kebahagiaan yang digunakan BPS adalah kepuasanhidup (34,80\%), perasaan (Afect, 31,18\%), dan makna hidup (eudaimonia, 34,02\%)(Sairi dkk, 2017).

Hal yang menarikdari data tersebut adalah orang-orang yang belum menikah cenderung lebih bahagia.Sementara berdasarkan berbagai sumber penelitian, pernikahan sangat erat hubungannya dengan kebahagiaan.Menurut Seligman berdasarkan data dari pusatri setopini nasional Amerika dari 35.00 warga yang disurvey selama 30 tahunterakhir, menunjukkan bahwa $40 \%$ orang yang menikah merasa sangat bahagia. Sedangkan untuk mereka yang mengalami perceraian, tidak menikah, dan ditinggal mati pasangan, sebesar $24 \%$ 
mengatakan sangat bahagia.

Salah satu komponen penting yang dikendaikan oleh masing-masing pribadidalam mencapai kebahagiaan adalah kebermaknaan hidup (Seligman, 2005). Kebermaknaan hidup memiliki salingketerkaitan yang besar dengan semua aspek kebahagiaan yang lain , bahkan tidak berlebihan jika dikatakan bahwa makna hidup hadir sebagai prasyarat munculnya kebahagiaan meskipun hal ini jarang dinyatakan secara eksplisit (Arif, 2016). Tingkat Kebermaknaan hidup yang tinggi berkaitan erat dengan kebahagiaan yang tinggi pula (Zhang,, 2017), sehingga menemukan makna hidup dalam kehidupan pernikahan, sangat penting untuk keberlangsungan pernikahan. Kalantarkousheh dan Hassan (2010) menemukan hubungan yang signifikan antara makna hidup dengan komunikas idalam pernikahan.Meskipun keduanya signifikan, namun hubungannya sedang (moderat). Lebih lanjut Bailey \& Fernando(2012) menemukan bahwa makna hidup memoderasi hubungan antara keterlibatan sosial dengan kebahagiaan, yang mana kebermaknaan hidup menunjukkan hubungan langsung yang kuat pada kebahagiaan.

Kebahagiaan dan kebermaknaan hidup merupakan sesuatu yang berbeda. Kebahagiaan besa rmengacu pada orientasi masa yang akan datang sementara makna hidup melibatkan masa lalu, masa kini dan masa yang akandatang(Baumeistera, 2013). Sehingga bagise seorang yang telah menikah, makna hidup akan berubah karena adanya perubahan integrasi dari masa lalu, masa kini dan masa yang akan datang. Maka kaitan antara kebahagiaan dan makna hidup adalah makna hidup memoderasi kebahagiaan. Jika dipadukan dengan hasil survey yang ada, maka kebahagiaan dipengaruhi oleh status pernikahan dimana kebermaknaan hidup turut serta sebagai prediktor dalam hubungan tersebut.

Dari paparan tersebut diatas dirumuskan hipotasesa mayor bahwa status perkawinan dan kebermaknaan hidup mempengaruhi kebahagiaan. Sedangkan hipotesa minor terdiri dari dua hipotesa, pertama kebahagiaan dipengaruhi kebermaknaan hidup, yang kedua satus perkawinan mempengaruhi kebermaknaan hidup.

\section{Metode}

Penelitian dilakukandenganmenggunakan pendekatan kuantitatif noneksperimen. dengan metode survey korelasional. Pada penelitian ini melibatkan variabel bebas, status pernikahan (menikah dan belum menikah), serta kebermaknaan hidup. Adapun variabel terikatnya adalah kebahagiaan.

Subyek

Dalam penelitian ini, subyek penelitian adalah mahasiswa perempuan yang berada pada usia 19-25 tahun yang ada di JawaTimur baik yang sudah menikah maupun yang belummenikah. Maka jumlah sampel dalam penelitian ini adalah 60 responden yang telah menikah, serta 79 responden yang belum menikah.

\section{Pegukuran}

Oxford Happiness Inventory (OHI) digunakan untuk mengukur kebahagiaan diadaptasi dari Peter Hillsdan Michael Argyle (2002).skala Oxford Happiness Inventory yang mempunyai aspek (1). Merasakan kepuasan hidup (Satisfaction with Life),, (2) Memiliki Harga Diri yang Positif(Positive Self Esteem) (3) Sikap Ramah Dalam Lingkungan Sosial (ocial Efficacy) (4) Memiliki Sikap Empati (Sociability/ Empathy), (5) Memiliki PolaPikir yang Positif (Positive Outlook), (6) Merasakan Kesejahteraan dalam Hidup 
(Well Being) , (7) Bersikap Riang dan Ceria (Cheerfullness),(Hills \& Argyle, 2001). Adapun hasil dari skala menunjukkan bahwa semakin tinggi nilai skala Oxford Happiness Inventory, menunjukkan seberapa tinggi kebahagiaan seseorang. Model penskoran dalam skala ini menggunakan jenis Likert dengan rentang satu sampai empat. Total aitem penelitian sebanyak 17 aitem dengan nilai reliabilitas alpha cronbach sebesara: 0,859. Hal ini menunjukkan bahwa skala Oxford Happiness Inventorypada penelitian ini sangat reliabel.

Kebermaknaan hidup diukur dengan skalaThe Brief Personal Meaningful Profile (PMP-B) dari Macdonald, Wong, \& Gingras, (2011). Skala PMP-B merupakan skala universal yang telah digunakan pada banyak penelitian.Skala ini terdiri dari tujuh dimensi yaitu Achievement Striving (Berusaha Berprestasi), Religion (Agama), Self-Transcendence (Kualitas Hidup), Self-
Acceptance (PenerimaanDiri), Intimacy (Kedekatan), Relationship (Hubungan), Fair Treatment (Perlakuan Yang Baik). Model penskoran dalam skala ini menggunakan jenis Likert dengan rentang satu sampai empat. Total aitem penelitian sebanyak 15 aitem dengan reliabilitas alpha cronbach sebesar $\alpha$ : 0,859. Hal ini menunjukkan bahwa skalaPMP-B pada penelitian ini sangat reliabel

\section{Hasil}

Hasil data diperoleh dengan menggunakan analisis deskripsi serta analisis koverian. Namun sebelum dilakukan analisis, terlebih dahulu uji asumsi kebahagiaan dan kebermaknaan hidup pada mahasiswa yangterdiridariuji normalitas, linieritas, serta uji homogenitas. Adapun dari analisis deskripsi, maka diperoleh data sebagai berikut.

Tabel 1. Hasil Uji Deskripsi

\begin{tabular}{lcccccc}
\hline Variabel & \multicolumn{3}{c}{ Hipotetik } & & & Empirik \\
& Maksimal & Minimal & Mean & Maksimal & Minimal & Mean \\
\hline $\begin{array}{l}\text { Kebahagiaan } \\
\begin{array}{l}\text { Kebermaknaanh } \\
\text { idup }\end{array}\end{array}$ & 68 & 17 & 42,5 & 55,914 & 48.3207 & 53,956 \\
& 60 & 15 & 37,5 & 51,685 & 50,04 & 50,863 \\
\end{tabular}

Dari Tabel 1 dapat diketahui bahwa tingkat kebahagiaan dan kebermaknaan hidup mahasiswa secara umum sudah baik. Hal ini dapat diketahui dari skor mean empirik lebih tinggi dari mean Hipotetik. Hasil tersebut menujukkan bahwa kebermaknaan hidup serta kebahagiaan mahasiswa lebih tinggi dari ekspektasi.

Hasil hipotesis penelitian mencakup hipotesis mayor dan hipotesis minor. Hasil hipotesis mayor dapat dilihat sebagai berikut.. Hasil dari pembuktian hipotesis mayor penelitian. Hipotesis mayor penelitian

memprediksi bahwa kebermaknaan hidup dan status pernikahan bersama-sama mempengaruhi kebahagiaan seseorang. Hasil uji Analisis Kovarian (anakova) menunjukkan bahwa kebermaknaan hidup serta status pernikahan memiliki pengaruh pada kebahagiaan seseorang. Hal ini dapat dilihat dari nilai $F=7.717$ dengan taraf signifikansi $0,006>0.05$. Kedua variabel tersebut memberikan kontribusi sebesar $5,4 \%$ dilihat dari tabel parcial eta Squared 0,054.

Hasil uji hipotesis mayor, dapat dilihat dari tabel 2 sebagai berikut. 
Tabel 2. Hasil Uji Hipotesis Minor

\begin{tabular}{llll}
\hline $\begin{array}{l}\text { Dependent } \\
\text { Variabel }\end{array}$ & Predictors & $\boldsymbol{F}$ & Signifikansi \\
\hline Kebahagiaan & MaknaHidup & 7,717 & 0,000 \\
& Status Pernikahan & 0,237 & 0,627 \\
\hline
\end{tabular}

Status pernikahan tidak memberi makna kebahagiaan pada masing-masing kontribusi terhadap kebahagiaan. Variabel orang. Hal inilah yang menjadikan makna maknahidup memiliki pengaruh signifikan hidup dan status perkawinan mempengaruhi terhadap kebahagiaandengan nilai kebahagiaan.

signifikansi $0,000<0,05$, sedangkanstatus Kebahagiaan pada orang yang lebih pernikahantidak mempengaruhi secara muda berkaitan erat dengan perasaan signifikan dengan0,627> 0,0).Prosentasi gembira, sedangkan pada orang yang lebih pengaruh makna hidup terhadap kebahagiaan tua memaknai kebahagiaan sebagai perasaan sebesar $56,1 \%$ sedangkan status pernikahan damai. Makna tersebut meliputi pemahaman mempengaruhi sebesar $0,2 \%$. Hal ini berarti pokok tentang keharmonisan, tujuan, dan hipotesis minor dalam penelitianini terbukti.

\section{Pembahasan}

Berdasar analisis data penelitian, kebermaknaan hidup dan status pernikahan secara bersama-sama mempengaruhi kebahagiaan seseorang. Namun terjadi hasil yang berbeda jika makna hidup dan status pernikahan dilihat secara terpisah. Kebermaknaan hidup dan status perkawinan secara bersama-sama mempengaruhi kebahagiaan sebesar $5,4 \%$. Dalam konteks kehidupan pernikahan, Kualitas pernikahan sangat bergantung pada penilaian kepuasan hidup serta kemampuan individu melakukan evaluasi terhadap kebahagiaan yang dirasakan. Sehingga kebahagiaan akan tetap dirasakan pada diri seseorang selama evaluasi terus menerus dilakukan secara kontinyu (Carr, Freedman, Cornman, \& Schwarz, 2014). Tentu saja hasil evaluasi setiap orang akan berbeda karena antara satu individu dengan individu lain pun berbeda dalam memaknai kesejahteraan hidup mereka. Hal ini pun terjadi pada mereka yang belum terikat dengan pernikahan. Kebahagiaan tetap dirasakan dengan melakukan evaluasi diri. Dalam hal ini, pasti akan terjadi perbedaan dan subyektifitas hubungan (Martelaa \& Stegerb, 2016). Dalam konteks penelitian ini, kebahagiaan diperoleh dengan memaknai kegembiraan dalam keharmonisan, mencapai tujuan maupun dalam hubungan. Keharmonisan diperoleh dengan memelihara hubungan baik dengan keluarga, teman, orang tua maupun dengan lingkungan sekitar. Kebahagiaan pun muncul dengan memaknai setiap langkah dalam mencapai tujuan.

Secara lebih rinci dengan memisahkan masing-masing variabel, kebermaknaan hidup mempengaruhi kebahagiaan secara signifikan sebesar $58 \%$. Artinya, perasaan bahagia yang muncul merupakan sikap yang dihasilkan dari pengalaman-pengalaman selama melewati pergumulan-pergumulan kehidupan. Sesuai denganBastaman (1998) bahwa makna hidup mempengaruhi kebahagiaan seseorang dengan memberikan kemanfaatan dalam kehidupan. Dengan makna hidup yang tinggi, maka akan lebih mudah seseorang mencapai kebahagiaan melalui hikmah dibalik setiap peristiwa hidup. Hikmah inilah yang menjadikan seseorang menemukan kebahagiaan sekalipun dalam peristiwa yang kurang menyenangkan. 
Status pernikahan memiliki pengaruh kecil sekali terhadap kebahagiaan yakni sebesar $0,2 \%$. Hal inilah yang menjadi perbedaan hasil penelitian ini dengan penelitian terdahulu yang mengemukakan bahwa orang yang menikah lebih bahagia karena pernikahan memiliki pengaruh kuat terhadap kebahagiaan (Bailey \& Fernando, 2012: Doblhamme, dkk., 2009: Gove, Style, \& Hughes, 2015). Terdapat beberapa kemungkinan penyebab perbedaan hasil penelitian terjadi diantaranya subyek yang digunakan dalam penelitian ini adalah keseluruhannya perempuan yang masih menjadi mahasiswa sehingga usia pernikahan belum terlalu lama. Pernikahan akan dirasakan perbandingan kebahagiaannya jika sudah mencapai 5 tahun pernikahan atau lebih, sedangkan pasca pernikahan berlangsung akan terasa bahagia namun seiring berjalan waktu kebahagiaan tersebut akan semakin turun setelah tahun pertama. Penurunan ini terjadi karena adanya adaptasi dalam pernikahan. Adaptasi ini akan dirasa cukup setelah pernikahan berusia dua tahun (Qari, 2014).

Kebahagiaan dalam penelitian ini, merupakan kondisi sejahtera yang ditandai oleh emosi positif seperti perasaan tentram, senang, puas terhadap kehidupan yang dijalani serta menikmati kehidupan, sehingga jika hasil menunjukkan bahwa semua subyek berbahagia, maka baik orang yeng telah menikah maupun belum menikah merasakan kesejahteraan, perasaa senang atau menikmati kehidupan.

Status perkawinan bersama dengan kebermaknaan hidup memberikan pengaruh tinggi pada kebahagiaan. Dengan hasil berbeda ketika variabel dipisahkan, maka dalam lingkup kebahagiaan bukan status perkawinan yang memiliki pengaruh, melainkan bagaimana memaknai hidupnya. Hasil penelitian ini sesuai dengan pemaparan data Badan Pusat Statistik yang menyatakan perbedaan tingkat kebahagiaan berdasarkan status perkawinan, namun yang perlu ditegaskan adalah, dengan perbedaan tersebut bukan berarti terdapat pengaruh didalamnya.

Sementara itu, analisis pengaruh masing-masing aspek terhadap kebahagiaan menunjukkan penerimaan diri memiliki pengaruh paling besar yakni $34 \%$ dan perlakuan baik memiliki pengaruh paling kecil yakni $15 \%$. Penerimaan diri memiliki hubungan yang erat dengan kebahagiaan. Dalam beberapa penelitian menunjukkan bahwa penerimaan diri yang tinggi menjadikan kebahagiaan tinggi pula (Lestiani, 2016; Yulistiana \& Prakoso, 2018). Dengan penerimaan diri yang tinggi, seseorang akan terhindar dari kecemasan, perasaan tidak mampu dan takut akan kritik dan penolakan serta bebas bereksplorasi dan mengejar halhal yang membahagiakan (Szentàgotai \& David, 2013). Terdapat hubungan signifikan antara penerimaan diri dengan emosi positif. Emosi positif mengindikasi adanya kebahagiaan seperti merasa puas dengan kehidupan, adanya perasaan senang, merasa sejahtera (Seligman, 2005).

Membandingkan data penelitian dengan hasil publikasi oleh Badan Pusat Statistik maka, perbedaan tingkat kebahagiaan tidak berpengaruh pada kebahagiaan. Yang menjadi pertimbangan adalah jika hasil seperti penelitian ini berlangsung secara kontinyu, maka seseorang tidak pelu menikah untuk mendapat kebahagiaan. Jika orientasi pernikahan adalah kebahagiaan, makan dampak yang mungkin terjadi adalah semakin menurunnya tingkat pernikahan karena anggapan menikah dan tidak sama 
saja. Maka yang perlu di pahami adalah makna dari setiap peristiwa dalam hidup yang mengantarkan pada kebahagiaan.

Memaknai setiap peristiwa kehidupan akan lebih mendalam jika menghayati setiap nilai-nilai agama maupun nilai-nilai aktifitas. Seperti menghayati kisah-kisah yang terdapat dalam kitab agama masing-masing, kisah para inspirator maupun para tokoh-tokoh. Dalam konteks agama islam proses mencapai kebahagiaan sangat erat dengan cerita nabi Ayyub yang telah melalui penderitaan berat hingga akhirnya menemukan kebahagiaan. Sama seperti dengan kisah tersebut, dalam kehidupan manusia kebahagiaan tidak bergantung seberapa besar sesuatu yang dimiliki atau diperoleh, namun seberapa dalam mampu memaknai peristiwa sehingga kebahagiaan dapat dirasakan.

Meskipun penelitian ini telah dilakukan sesuai dengan proedur yang tepat, namun perlu dipahami bahwa hasil penelitian ini masih banyak kekurangan. Antara lain jumlah subyek yang terbatas. Selain jumlah subyek, penelitian ini juga terbatas pada mahasiswa saja, sehingga terdapat kemungkinan hasil berubah dengan penelitian yang lebih kompleks.

\section{Kesimpulan}

Kesimpulan hasil penelitian yakni tingkat kebahagiaan dan kebermaknaan hidup pada subyek masuk dalam kategori tinggi baik bagi mereka yang terikat pernikahan maupun tidak. Secara keseluruhan $64,7 \%$ subyek memiliki kebahagiaan tinggi dan 35,3\% memiliki kebahagiaan sedang. Begitu pun dengan kebermaknaan hidup secara keseluruhan $82,7 \%$ tinggi dan $17,3 \%$ sedang. Jika dibedakan berdasarkan status perkawinan pada subyek yang menikah $70 \%$ memiliki kebahagiaan tinggi, 30\% memilikikebahagiaan sedang, 88,3\% memiliki makna hidup tinggi serta $11,7 \%$ memiliki makna hidup sedang. Pada subyek yang tidak terikat perkawinan menunjukkan kebahagiaan tinggi sebesar $60,8 \%$ serta 39,2\% memiliki kebahagiaan sedang, $\quad 78,5 \%$ memiliki kebermaknaan hidup tinggi, serta $21,5 \%$ memiliki makna hidup sedang.Status perkawinan dengan kebermaknaan hidup secara bersamasama mempengaruhi kebehagiaan sebesar $5,4 \%$. Sedangkan jika dilihat pengaruh secara terpisah, kebermaknaan hidup mempengaruhi kebahagiaan sebesar $56,1 \%$, dan status perkawinan dapat dikatakan tidak mempengaruhi kebahagiaan.

Peneitian yang akan datang akan lebih baik jika subyek menggunakan umur yang lebih bervariasi. Tentunya hal ini akan berpengaruh pada jumlah responden. Dengan usia subyek yang mewakili setiap jenjang, maka akan menghasilkan data yang lebih akurat daripada subyek yang hanya terbatas pada mahasiswa. Perlu dilakukan perbaikan terkait pemahaman lebih mendalam bagaimana memaknai suatu kebahagiaan dan kesenangan. Dengan begitu, maka dalam setiap aktifitas kehidupan, bukan rasa senang yang dicari melainkan bagaimana makna dirasakan. Ketika telah memahami makna dibalik setiap kejadian hidup, tidak ada yang perlu dikhawatirkan karena kebahagiaan akan terasa dari pemaknaan tersebut.

\section{Daftar Pustaka}

Arif, I. S. (2016). Psikologi Positif Pendekatan Saintifik Menuju Kebahagiaan. jakarta: Gramedia Pustaka Utama.

Bailey, A. W., \& Fernando, I. K. (2012). Routine and Project-Based Leisure, Happiness, and Meaning Life. Journal of Leisure Research , 139-154.

Bastaman, H. D. (1998). Meraih Hidup Bermakna Kisah Pribadi dengan 
Pengalaman Tragis. Jakarta:

Paramadina.

Baumeistera, R. F. (2013). Some key differences between a happy life and a meaningful life. The Journal of Positive Psychology, , 505-516.

Carr, D., Freedman, V. A., Cornman, J. C., \& Schwarz, N. (2014). Happy Marriage, Happy Life? Marital Quality and Subjective Well-being in Later Life. Journal of Marriage and Family , 930948.

Diener, E., Suh, E. M. Lucas, R. E \& Smith, H. L. (1999). Subjective Well-Being Three Decades of Progress. psychological Bulletin , 276-302.

Doblhammer, G.,Hoffmann, R., Muth, E., Westphal, C., \&Kruse. A (2009). A Systematic Literature Review of Studies Analyzing the Effect of Sex, Age, Education, Marital Status, Obesity and Smoking on Helath Transition. Max Planck Institute (pp. 37-64). Konrad-Zuse Str. 1, D-18057 Rostock . GERMANY: Demographic Research.

Gove, W. F., Style, C. B., \& Hughes, M. (2015). The Effect of Marriage on the Well Being of Adult A Theoritical Analysis. journal of Family Issue SAGE Social Science, 4-35.

Dush, C. M., \& Amato, P. R. (2005). Consequences of relationship status and quality for subjective well-being. Journal of Social and Personal Relationships , 607-627.

Hills, P., \& Argyle, M. (2001). The Oxford Happiness Questionnaire: a compact scale for the measurement of psychological well-being. Elsevier Science, 1073-1082.

Kalantarkousheh, S. M., \& Hassan, S. A. (2010). Function of life meaning and marital communication among Iranian Psouses in Universiti Putra Malaysia. Procedia Social and Behavioral Sciences Science Direct, 1646-1649.

Lestiani, I. (2016). Hubungan Penerimaan Diri dengan Kebahagaiaan pada Karyawan. Jurnal IImiah Psikologi, 109-119.

Macdonald, M. J., Wong, P. T., \& Gingras, D.
T. (2011). Meaning in Life Measures And Development of a Brief Version of the Personal Meaning Profile. TAF.

Martelaa, F., \& Stegerb, M. F. (2016). The Three Meanings of Meaning in Life: Distinguishing Coherence, Purpose, and Significance. The Journal of Positive Psychology , 11 (5), 531-545, DOI: 10.1080/17439760.2015.1137623.

Mineo, L. (2017, April 11). Harvard study, almost 80 years old, has proved that embracing community helps us live longer, and be happier. Dipetik april 12, 2018, dari the Harvard Gazette: https:// news.harvard.edu

Qari, S. (2014). Marriage, Adaptation and Happiness: Are there long-lasting gains to Marriage? Journal of Behavioral and Experimental Economics , 50: 29-39.http://dx.doi.org/10.1016/j. socec.2014.01.003

Rahardjo, W. (2007). Kebahagiaan Sebagai Suatu Proses Pembelajaran. Jurnal Penelitian Psikologi , 127-137.

Sairi M., Marhaeni, Harmawanti. Krismawati. Na'im, Akhsan. (2017, Desember 17). Indeks Kebahagiaan 2017. Retrieved Januari 12, 2018, from BPS.go.id: https://www.bps.go.id/ pressrelease/2017/08/15/1312/indekskebahagiaan-indonesia-tahun-2017sebesar-70-69-pada-skala-0-100.html

Seligman, M. E. (2005). Authentic Happiness Menciptakan Kebahagiaan dengan Psikologi Positif. Bandung: Mizan.

Szentàgotai, A., \& David, D. (2013). Self Acceptance and Happiness. In M. Bernard, The strength of selfacceptance. Rumania: Springer, 18-21.

Soulsby, L. K., \& Bennett, K. M. (2015). Marriage and Psychological Wellbeing: The Role of Social Support. Psychology, 6, 1349-1359

http://dx.doi.org/10.4236/ psych.2015.611132.

Wilson, C. M., \& Oswald, A. J. (2005). How Does Marriage Affect Physical and Psychological Health ? A Survey of Longitudinal Evidence. German: The Meaning(s) of Happiness. culture and 
health View project. Forschungsinstitut zur Zukunft der Arbeit Institute for the Study of Labor, 4-26.

Yulistiana, P., \& Prakoso, H. (2018). Hubungan Penerimaan Diri dengan Kebahagiaan pada Pasien Gagal Ginjal Kronis di RSHS. Proseding Psikologi , 185-192.

Zhang,, D. D. (2017). Meaning and its association with happiness, health and healthcare utilization: a cross-sectiona; Study. Journal of Affective Disorders , 1-36. 